\title{
Chromosomal anchoring of linkage groups and identification of wing size QTL using markers and FISH probes derived from microdissected chromosomes in Nasonia (Pteromalidae: Hymenoptera)
}

\author{
K.B. Rütten, ${ }^{a}$ C. Pietsch, ${ }^{b}$ K. Olek, ${ }^{a}$ M. Neusser, ${ }^{c}$ L.W. Beukeboom, ${ }^{d}$ and \\ J. Gadaub \\ a Biopsytec Analytik GmbH, Rheinbach; \\ b Institut für Verhaltensphysiologie und Soziobiologie, Universität Würzburg, Würzburg; \\ ${ }^{c}$ Department Biologie II, Institut für Anthropologie und Humangenetik, Ludwig-Maximilians-Universität München, \\ München (Germany); \\ ${ }^{\mathrm{d}}$ Center for Ecology and Evolutionary Studies, University of Groningen, Groningen (The Netherlands)
}

\begin{abstract}
Nasonia vitripennis is a small parasitic hymenopteran with a 50-year history of genetic work including linkage mapping with mutant and molecular markers. For the first time we are now able to anchor linkage groups to specific chromosomes. Two linkage maps based on a hybrid cross (N. vitripennis $\times N$. longicornis) were constructed using STS, RAPD and microsatellite markers, where 17 of the linked STS markers were developed from single microdissected banded chromosomes. Based on these microdissections we anchored all linkage groups to the five chromosomes of $N$. vitripennis. We also verified the chromosomal specificity of the microdissection through in situ hybridization and linkage analyses. This infor-
\end{abstract}

mation and technique will allow us in the future to locate genes or QTL detected in different mapping populations efficiently and fast on homologous chromosomes or even chromosomal regions. To test this approach we asked whether QTL responsible for the wing size in two different hybrid crosses $(N$. vitripennis $\times N$. longicornis and $N$. vitripennis $\times N$.giraulti) map to the same location. One QTL with a major effect was found to map to the centromere region of chromosome 3 in both crosses. This could indicate that indeed the same gene/s is involved in the reduction of wing in $N$. vitripennis and $N$. longicornis.

Copyright (C) 2003 S. Karger AG, Basel
The Nasonia species complex consists of three closely related species, Nasonia vitripennis, Nasonia longicornis and Nasonia giraulti, which differ in morphological and behavioral traits. $N$. longicornis and $N$. giraulti are restricted to western and eastern North America, respectively, whereas $N$. vitripennis is cosmopolitan and occurs in both sympatric and allopatric populations with the other two species. In nature the three species are reproductively isolated by infections with different

\footnotetext{
J.G. and C.P. were supported by two grants of the DFG, SFB 554-B1 and GA 661/1 Received 2 October 2003; manuscript accepted 22 December 2003.

Request reprints from Jürgen Gadau, Universität Würzburg-Biozentrum Institut für Verhaltensphysiologie und Soziobiologie

Am Hubland, 97074 Würzburg (Germany); telephone: +49 9318884305

fax: +49 931888 4309; e-mail: Jgadau@biozentrum.uni-wuerzburg.de
}

strains of Wolbachia bacteria, which cause bidirectional cytoplasmatic incompatibility in interspecies crosses. However, Nasonia can be cured of their Wolbachia and Wolbachia free lines can produce viable and fertile hybrids. Nasonia has a haplodiploid sex determination system where males are produced from unfertilized eggs. The possibility to study haploid hybrid or non-hybrid males is also a great advantage for genetic studies because dominant interactions between alleles of the same locus are absent. From highly inbred lines we used nonhybrid haploid males for chromosome microdissection and FISH and hybrid haploid males for linkage mapping.

Nasonia currently develops into a hymenopteran model organism (Page et al., 2002; Shuker et al., 2004) for several evolutionary (speciation, Bordenstein et al., 2001; genetic basis of hybrid breakdown (Gadau et al., 1999, 2002), behavioral (genetic basis of courtship, Beukeboom and van den Assem, 2002) \begin{tabular}{lll}
\hline KARGER & $\begin{array}{l}\text { Fax }+41613061234 \\
\text { E-mail karger@karger.ch } \\
\text { www. karger.com }\end{array}$ & ○ 2004 S. Karger AG, Basel \\
$0301-0171 / 04 / 1051-0126 \$ 21.00 / 0$
\end{tabular}
Accessible online at:

www. karger.com/cgr 
and developmental questions, respectively. However, to proceed further with the genetic analysis, it is necessary to develop reliable molecular markers that are physically anchored, so that linkage of any molecular markers/genes can easily be exchanged between the different Nasonia working groups. Ultimately, the combination of all anchored markers of different research groups will result in a dense map for all five chromosomes of Nasonia, a major advantage for example for fine mapping and positional cloning.

In recent years a variety of different methods for microsatellite isolation have been published and best results have been achieved when using an enrichment procedure before cloning (e.g. Rütten et al., 2001). To isolate microsatellite and other STS markers from specific chromosomes, we decided to microdissect the chromosomes and use this chromosomal DNA as a starting point for further marker development by the same enrichment protocol. For microdissection, the chromosomes had to be prepared and identified first. Chromosome studies in Nasonia have a long history. The first description goes back to 1946 when Gershenzon reported the existence of five chromosomes in Nasonia. The discovery of a parasitic B-chromosome in Nasonia (Nur et al., 1988) focused again on the karyotype of the wasp. In 2000, Gokhman and Westendorff presented a key for the identification of the chromosomes of all three species of the genus Nasonia. For their description they used a very precise measurement of the chromosomal arms after Giemsa staining and/or C-banding. However, since all five chromosomes of Nasonia are metacentric and some vary only slightly in size, it is still hard to identify the different chromosomes by C-banding routinely for microdissection. Therefore, we used GTG-banding and developed a key that allowed us to easily identify all five chromosomes due to a combination of structural characters and size differences.

Chromosomal microdissection techniques, in which whole chromosomes or specific chromosomal regions can be isolated and used for further genetic manipulations, have been available since the 1980s. The major problem that goes along with this technique is the minute amount of DNA that is obtained when working with only a single chromosome. This problem might be solved with strategies like linker adapted PCR or DOP-PCR that increase the DNA amount. However, these techniques generate new problems because they are all highly sensitive to contamination. So far these microdissection techniques have been mostly used for human or commercially bred plants or animals. To our knowledge it has never been used in insects with the exception of the polytene chromosomes of Drosophila.

The objectives of this study were to (i) develop reliable microsatellite and other STS markers for the genus Nasonia and (ii) generate a new chromosomal anchored linkage map. These markers will enhance the compatibility between different research groups of the Nasonia community, can be used for FISH and for the screening of BAC clones (in a newly developed BAC library available at "Clemson University Genomic Institute") and are a further step towards the isolation of the genes underlying specific QTL. Finally, we started with the mapping of QTL for the differences in male wing size between $N$. vitripennis and $N$. longicornis to test whether the QTL for wing size map to the same position as previous wing size QTL derived from a different hybrid cross (N. vitripennis and N. giraulti, Gadau et al., 2002).

\section{Materials and methods}

\section{Nasonia lines and mapping populations}

Both mapping populations of $\mathrm{F}_{2}$ hybrid males were derived from crosses between $N$. longicornis line IV7R2 (males) and $N$. vitripennis line ASYMC (females) further called LV cross. Since different markers, RAPDs respectively microsatellites and STS markers, were predominantly used in the two linkage studies, we will further use the following denotation: (I) LV-RAPD map (= LV cross, $\mathrm{n}=106$ ); (ii) LV-ms map (= LV cross; mapping of wing size, $\mathrm{n}=96$ ). To homologize two LGs with multiple wing size QTL from a previous interspecific cross (Gadau et al., 2002) we set up crosses between three $N$. vitripennis mutant lines (stDR, st5215 and or 123) and our standard N. longicornis line. The F2 haploid males of this interspecific cross were phenotyped and then genotyped for 10 microsatellite loci, two from each linkage group (LG). Significant association between phenotype and genotype was determined by $\chi^{2}$ tests.

\section{Measurements}

Wing size was measured from mounted forewings of males from the LVms mapping population under a dissection microscope and $40 \times$ magnification as described in Gadau et al. (2002).

Molecular analysis: DNA extraction of $F_{2}$ males was done for both LV crosses according to Gadau et al. (1999). RAPD amplifications were performed according to Gadau et al. (1999).

Linkage analysis: Mapmaker (Lander et al., 1987, version 2.0 for the Macintosh) was used to analyze the data and construct a chromosomal anchored linkage map. The data type was coded as "haploid" and the mapping procedure followed the standard protocol described in Gadau et al. (1999). For the LV-ms linkage map the two-point linkage analysis was first calculated with a setting of $\mathrm{LOD}=2, \theta=0.4$ to find a preliminary set of linkage among the chromosome specific markers $(n=16)$. When integrating other markers like microsatellites (derived from an enriched genomic library) or RAPDs $(n=32)$, the setting in the two-point linkage analysis was increased to $\operatorname{LOD}=3, \theta=0.4$. Multipoint analysis within all putative linkage groups was always done with $\mathrm{LOD}=3, \theta=0.4$. All map distances $(\mathrm{cM})$ were calculated from recombination fractions (\%) according to Kosambi's mapping function (Kosambi, 1944). For the LV-RAPD linkage map the setting for both the two-point and multipoint analysis was $\operatorname{LOD}=5$ and $\theta=0.25$.

\section{QTL analysis}

MapQTL 4.0 (van Ooijen et al., 1999) was used to identify QTL. First a standard interval mapping was done to identify putative QTL. Then MQM mapping (multiple-QTL model), implemented in MapQTL, was used to fit more than one QTL at a time. The MQM mapping procedure uses markers closest to the QTL as cofactors to take over the role of the QTL. Thus, the cofactors will reduce the residual variance, increase the power in the search for other segregating QTL, and enhance the accuracy of QTL mapping (Jansen, 1993, 1994; Zeng, 1993, 1994; Jansen and Stam, 1994). Statistical significance of each QTL was confirmed using the standard permutation test for interval mapping (Churchill and Doerge, 1994) incorporated in MapQTL 4.0 (van Ooijen et al., 1999).

\section{Microdissection and marker development}

Chromosome preparation and banding: Chromosomes of $N$. vitripennis (ASYMC) were prepared from cerebral ganglia of male prepupae according to the standard protocol of Imai et al. (1988). Minor modifications were performed according to the careful handling that was required because all preparations were made on coverslips for later microdissection. The air dried chromosomes were GTG-banded by incubation in $0.05 \%$ trypsin in PBS for $5 \mathrm{~min}$ at $37^{\circ} \mathrm{C}$, and subsequent incubation in $70 \%$ ethanol followed by 3 min of Giemsa staining.

Microdissection of single chromosomes: Single chromosomes of metaphase plates were microdissected using an Eppendorf-micromanipulator and fine glass needles attached to an inverted microscope (Zeiss Axiovert 200) with $1,000 \times$ magnification. Before microdissection a drop of water was 
placed on the chromosomes, making them soft and sticky to the needle. The dissected chromosome was transferred into a small tube by breaking off the tip of the needle in $5 \mu$ collection buffer $(40 \mathrm{mM}$ Tris- $\mathrm{HCl}, \mathrm{pH} 7.5,20 \mathrm{mM}$ $\mathrm{MgCl}_{2}, 50 \mathrm{mM} \mathrm{NaCl}, 25$ pmol DOP-PCR primer CCGACTCGAGNNNNNNATGTGG, $2 \mathrm{mM}$ each dNTP, $2.5 \mu \mathrm{g}$ proteinase $\mathrm{K}$ [purified for PCR]). The probe was incubated at $37^{\circ} \mathrm{C}$ overnight, followed by incubation at $90^{\circ} \mathrm{C}$ for $10 \mathrm{~min}$.

Amplification of dissected DNA: An initial 8 cycles of PCR (denaturation for $1 \mathrm{~min}$, annealing at $30^{\circ} \mathrm{C}$ for $2 \mathrm{~min}$, and extension at $37^{\circ} \mathrm{C}$ for $2 \mathrm{~min}$ ) was conducted by adding $0.2 \mu \mathrm{l}$ of diluted (1:8) T7 DNA polymerase (Sequenase version 2.0, USB) at each cycle. Following this pre-amplification step $45 \mu 1$ of a DOP-PCR Master mix (2.5 units Taq DNA polymerase in Brij 35, $200 \mu \mathrm{M}$ each dNTP, $10 \mathrm{mM}$ Tris- $\mathrm{HCl}, 50 \mathrm{mM} \mathrm{KCl}, 1.5 \mathrm{mM} \mathrm{MgCl}_{2}, 2 \mu \mathrm{M}$ primer as above, DOP-PCR-Master Kit, Roche) was added to the probe and a conventional PCR-reaction was performed. This PCR was performed with an initial denaturation of $95^{\circ} \mathrm{C}$ for $3 \mathrm{~min}, 35$ cycles of $1 \mathrm{~min}$ denaturation at $94^{\circ} \mathrm{C}$, $1 \mathrm{~min}$ annealing at $56^{\circ} \mathrm{C}, 2 \mathrm{~min}$ extension at $72^{\circ} \mathrm{C}$, followed by a final extension time of $5 \mathrm{~min}$ at $72^{\circ} \mathrm{C}$

Control of DOP-PCR product and amplification for repeat isolation: To verify the success of the microdissection and to estimate the effectiveness and degree of contamination of the amplified DNA, a dot blot experiment was conducted. The generation of the probe was conducted via a second DOP-PCR in which $1 \mu \mathrm{l}$ of the previously obtained DOP-PCR product was transferred. This second DOP-PCR contained $16 \mathrm{mM}\left(\mathrm{NH}_{4}\right)_{2} \mathrm{SO}_{4}, 67 \mathrm{mM}$ Tris- $\mathrm{HCl} \mathrm{pH} 8.8,0.01 \%$ Tween, $150 \mu \mathrm{M} \mathrm{MgCl}_{2}, 20$ pmol DOP primer (see above), $200 \mu \mathrm{M}$ each dNTP except $130 \mu \mathrm{M}$ dTTP and $70 \mu \mathrm{M}$ digoxigenin11 -dUTP in a total volume of $20 \mu \mathrm{l}$. The PCR-program consisted of $5 \mathrm{~min}$ at $95^{\circ} \mathrm{C}$ for initial denaturation and 16 cycles of 1 min denaturation at $94^{\circ} \mathrm{C}$ $1 \mathrm{~min}$ annealing at $56^{\circ} \mathrm{C}, 2 \mathrm{~min}$ extension at $72^{\circ} \mathrm{C}$ followed by a final extension step at $72^{\circ} \mathrm{C}$ for $10 \mathrm{~min}$. The labeled PCR product was hybridized overnight at $42^{\circ} \mathrm{C}$ to a blot containing a dot of $600 \mathrm{ng}$ human DNA as a negative control and the same amount of Nasonia DNA as a positive control. After hybridization two steps of washing with low stringency were performed in $2 \times$ SSC and $0.1 \%$ SDS at room temperature followed by two steps of washing with high stringency at $68^{\circ} \mathrm{C}$ in $0.1 \times \mathrm{SSC}, 0.1 \% \mathrm{SDS}$. Hybridized probes were detected using anti-Dig-Fluorescence Fab-fragments (Roche) and CDPStar (Roche)

Probes for the fluorescence in situ hybridization (FISH): Amplified microdissected DNA from a second previously described DOP-PCR was labeled with biotin-16-dUTP, or with digoxigenin-11-dUTP or with tamralabeled dUTPs in a third PCR reaction identical to the second DOP-PCR amplification except for the addition of the different labeled dNTPs. A sequential FISH procedure (two hybridizations) was used to mark all five chromosomes with three labels (digoxigenin, biotin and tamra).

Enrichment of repetitive genetic elements: Since repetitive genetic elements are well suited for marker development, the following isolation procedure was conducted (with the chromosome specific DNA probes). Another second DOP-PCR with $200 \mu \mathrm{M}$ each dNTP and no dig-dUTP was performed as described above. After amplification $1 \mu \mathrm{g}$ of a $3^{\prime}$-biotin-labeled (CA) ${ }_{10}$ oligonucleotide was added to the PCR product and the total volume was adjusted to $100 \mu \mathrm{l}$ with $6 \times \mathrm{SSC}$. The DNA was denatured for $10 \mathrm{~min}$ at $95^{\circ} \mathrm{C}$ and subsequently chilled on ice. In order to let the oligos hybridize to the DOP-PCR products, an incubation of $5 \mathrm{~min}$ at room temperature followed. According to the standard protocol of Fisher and Bachmann (1989) streptavidin-coated magnetic beads (Dynal) were bound to the hybrid molecules and captured using a magnetic particle concentrator (Dynal). Three steps of washing were performed to discard unhybridized DNA fragments. In the first step $100 \mu \mathrm{l}$ of $2 \times$ SSC was used at room temperature, in the second step $1 \times$ SSC was used instead, and in the third step $1 \times \mathrm{SSC}$ was used at $57^{\circ} \mathrm{C}$. Captured DNA

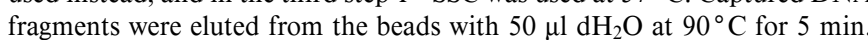
$15 \mu l$ of the eluted DNA was again DOP-PCR amplified in a total volume of $50 \mu \mathrm{l}$ using the components of the DOP-PCR Masterkit (Roche) and the following PCR-program: an initial denaturation of $5 \mathrm{~min}$ at $95^{\circ} \mathrm{C}, 20$ cycles of 1 min denaturation at $94^{\circ} \mathrm{C}, 1 \mathrm{~min}$ annealing at $56^{\circ} \mathrm{C}, 3 \mathrm{~min}$ extension at $72^{\circ} \mathrm{C}$ followed by a final extension step at $72^{\circ} \mathrm{C}$ for $20 \mathrm{~min}$.

Cloning and sequencing of PCR products: $2 \mu \mathrm{l}$ of the PCR products were directly cloned into TA cloning vector (Invitrogen) according to the manufacturer's protocol. After overnight ligation and subsequent transformation positive white colonies were picked and transferred into 96-well cell culture cluster plates containing LB medium with $100 \mu \mathrm{g} / \mathrm{ml}$ ampicillin. After culturing for $16-18 \mathrm{~h}$, glycerol was added to a final concentration of $15 \%$. The chromo- some-specific library was stored at $-80^{\circ} \mathrm{C}$. Single colonies were also individually cultured in $4 \mathrm{ml} \mathrm{LB}$ medium with $100 \mu \mathrm{g} / \mathrm{ml}$ ampicillin for further sequencing. Plasmid DNA was prepared using the Plasmid Mini Kit (Macherei and Nagel) according to the manufacturer's protocol. Sequencing reactions were performed in the "value read" level by MWG GmbH

Analysis of sequences and primer design: All sequences proved to be nonhuman using the Blast-function of the NCBI GenBank. For the amplification of chromosome-specific repetitive DNA fragments of Nasonia primers were designed in the flanking regions. Most primers were calculated to anneal at 54 and $56^{\circ} \mathrm{C}$ due to the addition of $2{ }^{\circ} \mathrm{C}$ for $\mathrm{A}$ and $\mathrm{T}$ and $4{ }^{\circ} \mathrm{C}$ for the bases $\mathrm{G}$ and $\mathrm{C}$. For the detection of PCR products on an automated sequencer (ABI 377) all forward primers were labeled with fluorescent dyes. Sequences of the primers and their fluorescent label are listed in the supplement.

PCR amplification, gel electrophoresis and band scoring: Multiplex-PCRs were carried out in a volume of $30 \mu \mathrm{l}$ with $5 \mathrm{ng}$ genomic DNA, $10 \mathrm{pmol}$ each of the different primer pairs. Markers that were used in the different multiplex-PCRs are listed in Appendix 1. All multiplex-PCRs were conducted with the following amplification program: $15 \mathrm{~min}$ initial denaturation and activation of the hot start Taq polymerase, 30 cycles of 1 min denaturation at $95^{\circ} \mathrm{C}, 1 \mathrm{~min}$ annealing at $50^{\circ} \mathrm{C}, 1 \mathrm{~min}$ extension at $72^{\circ} \mathrm{C}$ and a final extension time of $10 \mathrm{~min}$ at $72^{\circ} \mathrm{C}$. The amplification product was diluted $1: 10$, mixed with formamide, loading dye and an internal size standard (LS 350, Serac). After denaturation at $94^{\circ} \mathrm{C}$ for $2 \mathrm{~min}$, PCR products were electrophoresed in a $6 \%$ denaturing polyacrylamide gel. The size of the different PCR products was determined using Genescan and Genotyper software programs (PE Applied Biosystems).

Microsatellite isolation from genomic DNA

Microsatellites were isolated from $2 \mu \mathrm{g}$ genomic DNA according to the procedure described in Rütten et al. (2001).

FISH: Fluorescence in situ hybridization (FISH) of $N$. vitripennis chromosome 1-5 probes established by microdissection was performed according to the protocol for sequential FISH described in Müller et al. (2002). The chromosome probes were labeled by DOP-PCR (Telenius et al., 1992) in the presence of biotin-dUTP, tamra-dUTP or digoxigenin-dUTP. The five probes were divided in two subsets that were sequentially hybridized in $50 \%$ formamide, $10 \%$ dextran sulphate, $1 \times \mathrm{SSC}$ at $37^{\circ} \mathrm{C}$ to the same $N$. vitripennis metaphase preparation. Of each labeled probe, approximately $2 \mu \mathrm{g}$ was used. Subset 1 was composed of chromosome 1 (tamra-dUTP), 2 (biotindUTP) and 3 (digoxigenin-dUTP). Posthybridization washings were performed with $50 \%$ formamide, $10 \%$ dextran sulphate, $1 \times \operatorname{SSC}(2 \times 5 \mathrm{~min}$, $\left.45^{\circ} \mathrm{C}\right), 2 \times \operatorname{SSC}\left(2 \times 5 \mathrm{~min}, 45^{\circ} \mathrm{C}\right)$ and $0.1 \times \mathrm{SSC}\left(1 \times 5 \mathrm{~min}, 60^{\circ} \mathrm{C}\right)$. Biotin was detected by one layer avidin- $\mathrm{Cy} 5$, digoxigenin by one layer of FITCconjugated sheep anti-digoxigenin antibody. After hybridization and detection of the first probe subset, microscopic images were acquired and the cell coordinates were recorded. Subsequently, the cells were rehybridized with the second probe subset (chromosome 4 , biotin-dUTP and 5, digoxigenindUTP), followed again by posthybridization washings, detection and microscopy.

\section{Results}

Karyotypes and chromosome identification: All (about 90) male metaphase plates studied contained five chromosomes. Size differences were only used as a criterion for identification in metaphase plates with slightly condensed chromosomes. The GTG banding brought up slight differences in the structure of the chromosomes, but only a few banding patterns proved to be constant. However, with a combination of size and chromosome-specific staining we could unambiguously identify all five chromosomes of $N$. vitripennis (Fig. 1). Chromosome 1 is by far the largest chromosome. Only slight size differences exist between chromosomes 2 and 4 and chromosomes 3 and 5, but in combination with GTG staining it was possible to distinguish and identify all chromosomes of a metaphase plate. The observed constant differences were a subcentromeric appear- 
GTG banding of $N$, vitripennis

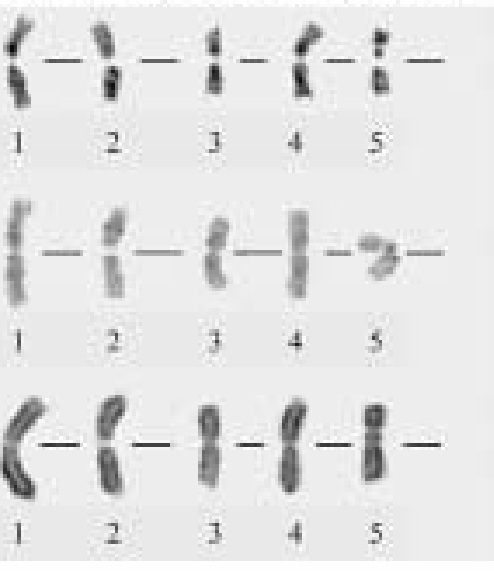

Fig. 1. (a) GTG-banded chromosomes of three $N$. vitripennis males. Chromosomes are numbered and ordered according to size and structure (Gokhman and Westendorff, 2000). (b) Multicolor FISH with chromosome-specific DOP-PCR products as probes (chr. 1 = yellow; chr. 2 = purple; chr. 3 = red; chr. 4 = light blue; chr. $5=$ green).

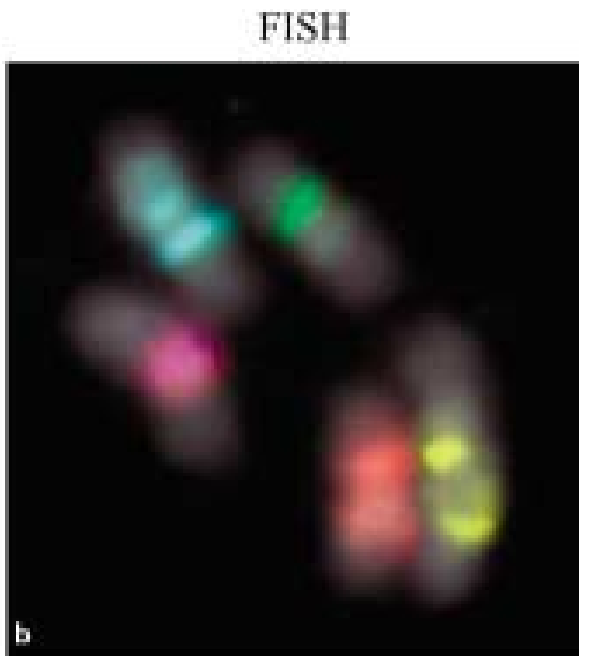

ance of the smallest chromosome 5 and a major signal in the middle of the short arm of chromosome 2 (Fig. 1). Note, in contrast to Gokhman and Westendorff (2000), we decided to not only use size as a factor to name chromosomes, rather we also incorporated our mapping results. Therefore, chromosome 4 is slightly larger than chromosome 3 . Chromosome 4 was named to avoid confusion with earlier publications, where the mutant marker or 123 has so far always been associated with linkage group IV (e.g. Gadau et al., 1999; Saul, 1993; Weston et al., 1999). If we would have used size as the sole factor, this would have been chromosome 3 . Additionally, stDR maps to chromosome 5 which has so far been associated with LG I, but here we decided not to use this old linkage group designation because chromosome 5 is the smallest chromosome.

Microdissection of single chromosomes: Only single chromosomes were microdissected to ensure the chromosome-specific origin of the markers that were consecutively constructed based on the isolated chromosomal DNA. Two technical tricks made the microdissection very efficient. Wetting the preparation made the chromosomes sticky to the needle and prevented electrostatic interactions resulting in the loss of the dissected fragment when put into the collecting vial. In addition, gloves and vial were treated with antistatic spray.

DOP-PCR: Two consecutive DOP-PCR (first and second rounds) were conducted on the dissected chromosomal material. Using this approach the purity and effectiveness of the initial and all further amplifications can be controlled and there is always stock of material left which can be used for further experiments. The purity of the DOP-PCR products was tested with a dot-blot approach where human DNA served as a negative control. The dot-blot tests were both very sensitive and good predictors of the effectiveness of subsequent experiments. Only those DOP-PCR products were used for the isolation of chromosome-specific markers which proved in the dot-blot analysis to be only minimally contaminated.

Isolation of repetitive DNA sequences: Although a specific enrichment procedure for repetitive DNA sequences from the second round DOP-PCR product of the microdissected chro- mosomes has been used, only a few clones contained pure microsatellites while most of the sequenced clones showed other repetitive elements. However, even non-repetitive sequences can be used for the design of markers for linkage mapping in hybrid populations because almost all tested sequences were variable between the three Nasonia species. From these sequences we designed at least one marker for each chromosome (thirteen for chr. 1; one for chr. 2, two for chr. 3, two for chr. 4 and one for chr. 5). Using the conventional microsatellite isolation method we designed and mapped primers for another 10 loci.

Mapping and QTL analysis: For the LV-RAPD and LV-ms map we mapped 63 and 48 markers, respectively (Fig. 2). The maps span $764.3 \mathrm{cM}$ (LV-RAPD) and $624.5 \mathrm{cM}$ (LV-ms) with an average distance between two markers of 12.5 and $13 \mathrm{cM}$, respectively. The mean recovery rate of all mapped markers was normally distributed and slightly biased towards vitripennis alleles (both crosses had a vitripennis cytoplasm) but not significantly different from $50 \%$ (mean \pm SD: LV-RAPD $=$ $0.55 \pm 0.114 ;$ LV-ms $=0.54 \pm 0.083$; Fig. 3 , Table 1). A comparison of the RAPD and microsatellite/STS markers in the LV-ms cross showed no significant differences in recovery rate between marker type $(\mathrm{ms}=0.56 \pm$ RAPD $0.53 \pm$, MannWhitney U test n.s.).

To anchor the LV-RAPD linkage groups to specific chromosomes of the LV-ms map, we genotyped individuals of both maps with eleven identical RAPD markers and one microsatellite marker, respectively (Fig. 1).

For the QTL analyses the following traits wing length, wing width and two composite measurements wing length/head size and wing width/head size were analyzed (for details on measurement see Gadau et al., 2002). Three significant QTL were found, two on chromosome 1 and one on chromosome 4 (Table 2, Fig. 2).

To homologize linkage groups of another hybrid cross (N. vitripennis and $N$. giraulti) to compare the distribution of QTL for wing size between these two crosses, we mapped eye-color genes in the LV-ms map which were previously mapped in this 


\section{chr. 1}

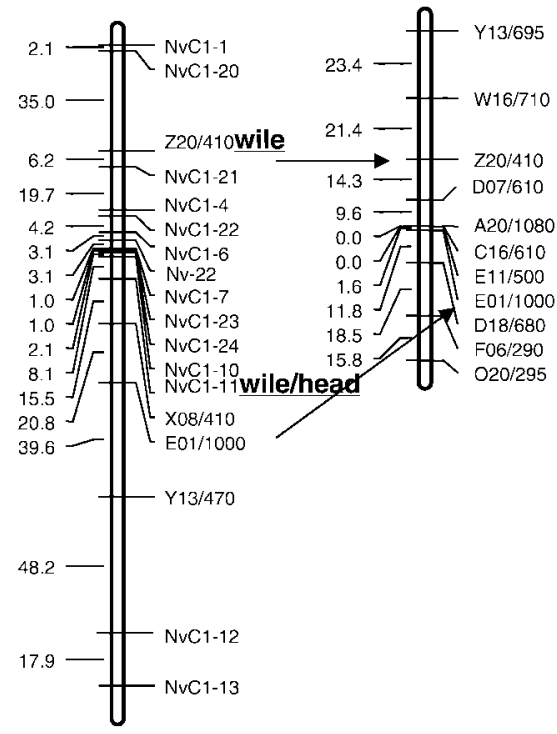

chr. 3

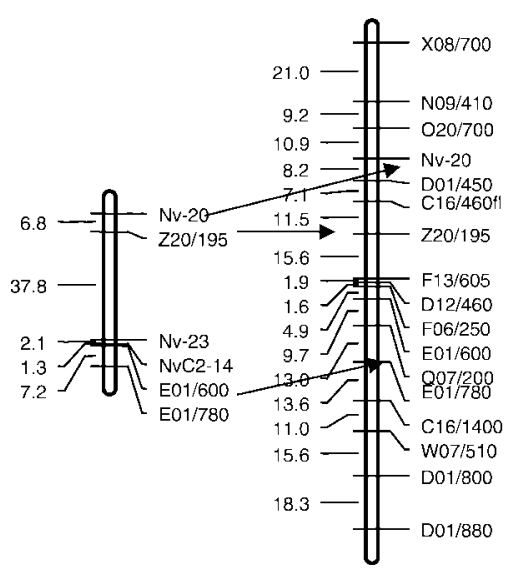

chr. 5

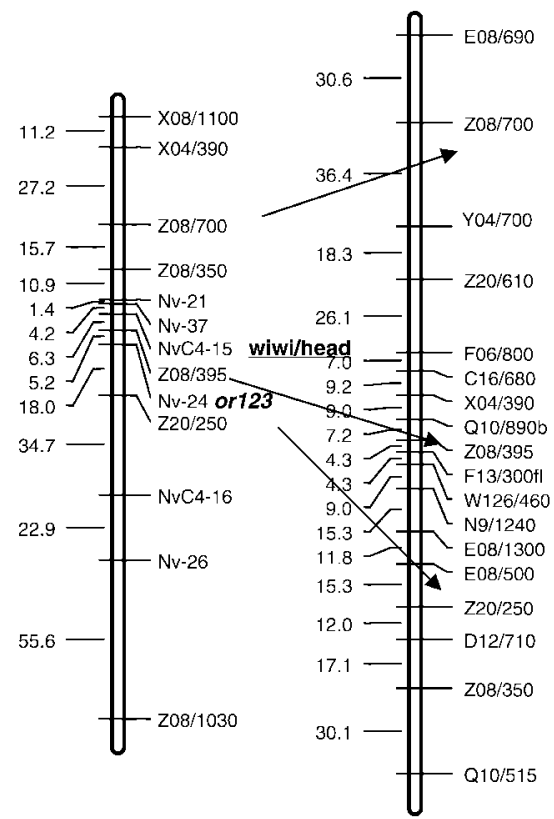

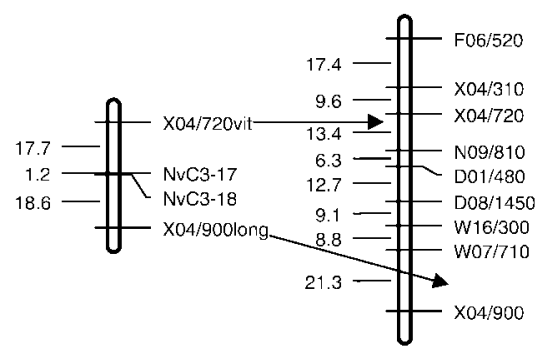

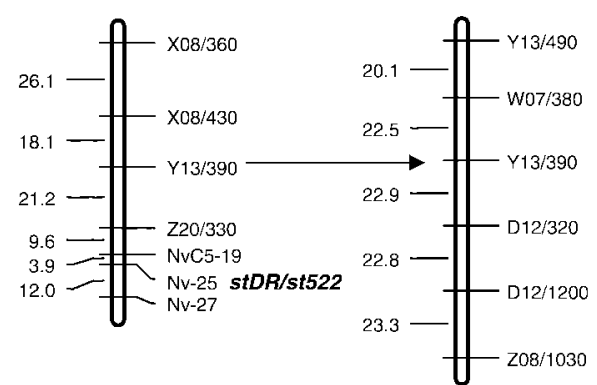

Fig. 2. Chromosomal anchored linkage maps based on two mapping populations of $N$. longicornis $\times N$. vitripennis hybrid $\mathrm{F} 2$ males. Linkage groups on the left side are predominantly based on microsatellite markers (chromosome-specific and unspecific). QTL for wing size are indicated towards the right of the markers with the largest effect (see Table 1). Linkage groups on the right side are predominantly based on RAPD markers and where chromosomal anchored by RAPD or microsatellite markers shared with the chromosomal anchored linkage map on the left side. QTL for wing size (bold and italics) are also given on the right side of the marker with the largest effect (for designation see Table 2).

other hybrid cross. The loci stDR and st5215 mapped to chromosome 5 (it was previously known that both loci are linked) and or 123 to chromosome 4.

\section{Discussion}

The use of markers (STS/microsatellites) derived from PCR pools based on microdissected individual chromosomes allowed us to physically link linkage groups of three independent linkage maps to individual chromosomes (Fig. 2). The chromosome specificity of the DOP-PCR pools was nicely demonstrated by sequential FISH of all five chromosomes in one metaphase plate (Fig. 1). The unequal distribution of the signal might demonstrate a non-homogeneous amplification of the chromosomal DNA. This could have been caused by the many PCR cycles that were required to increase the amount of dissected DNA. These chromosome-specific DOP-PCR pools are also valuable tools for chromosome-specific marker enrichment procedures. They will allow us to effectively cut our efforts to a fifth compared to an unspecific marker enrichment because once we localized a QTL to a specific chromosome we can concentrate the screening for additional markers for fine mapping on one chromosome-specific DOP-PCR pool. This effort can even be further reduced when we microdissect only specific regions of a chromosome containing a specific QTL marked with closely linked or better flanking markers. For this approach it is possible to pool many dissected fragments and to develop markers from this pool. In this case the above described markers are usable to confirm the origin of the new 
Table 1. STS and microsatellite markers used for mapping. The nomenclature of loci was according to the following logic: Nv stands for $N$. vitripennis, the next number stands for the chromosome and the number after the dash is a serial number; e.g., locus NvC1-4 was derived from a microdissection of a $N$. vitripennis chromosome 1 and possesses the serial number 4 . In contrast, loci with $\mathrm{Nv}$ and a single number were developed from a standard microsatellite isolation based on genomic DNA, e.g. Nv-22.

\begin{tabular}{|c|c|c|c|c|c|c|}
\hline Locus & Marker $^{\mathrm{a}}$ & primer sequence [ $\left.5^{\prime}-3^{\prime}\right]$ & $\begin{array}{l}\mathrm{Ta}^{\mathrm{b}} \\
\left({ }^{\circ} \mathrm{C}\right)\end{array}$ & $\begin{array}{l}N . \text { vitripennis } \\
\text { Size (bp) }\end{array}$ & $\begin{array}{l}N . \text { longicornis } \\
\text { Size (bp) }\end{array}$ & $\begin{array}{l}\text { GenBank } \\
\text { accession no. }\end{array}$ \\
\hline \multicolumn{7}{|c|}{ Chromosome 1} \\
\hline NvC1-1 & STS & $\begin{array}{l}\text { TTC TTT GAT CTT AGC GTG G } \\
\text { CAC CGA AAG CCA ATC AGC }\end{array}$ & 50.0 & 137 & - & AY571870 \\
\hline $\mathrm{NvC1-4}$ & STS & $\begin{array}{l}\text { GCT CAG CAA CAG CAG ATC AAG } \\
\text { CGT AAT GCG TAT CCG AAA ACG }\end{array}$ & 59.0 & 117 & - & AY571871 \\
\hline $\mathrm{NvC1-6}$ & STS & $\begin{array}{l}\text { GGT TGC TTT TAA GTC TTT GC } \\
\text { CTG GTC TTC TGC ATA ATG G }\end{array}$ & 50.0 & 140 & 142 & AY571872 \\
\hline $\mathrm{NvC1-7}$ & STS & $\begin{array}{l}\text { AGT CTT ATG TGA TCT CAA CG } \\
\text { AAA TCA TTT TAC ACG CAG AAG }\end{array}$ & 50.0 & 146 & - & AY571873 \\
\hline $\mathrm{NvC} 1-10$ & STS & $\begin{array}{l}\text { AGA AGG AGA GAA TGC TCG } \\
\text { GAG ATA GTG CCC ATC ATC }\end{array}$ & 50.0 & 115 & - & AY571874 \\
\hline $\mathrm{NvC1}-11$ & STS & $\begin{array}{l}\text { CCT TAC GCA TTT TTT GAG C } \\
\text { CGA TAG AAA GCT CTG AAC G }\end{array}$ & 50.0 & 203 & - & AY571875 \\
\hline $\mathrm{NvC1} 12$ & STS & $\begin{array}{l}\text { TCG CAT TTT ACA TCT CTT TC } \\
\text { GAG ATA AAC GAA TCA AAA GAC }\end{array}$ & 50.0 & 146 & - & AY571876 \\
\hline $\mathrm{NvC1} 13$ & STS & $\begin{array}{l}\text { TAA AAG TAT TAG ACC TTT GGG } \\
\text { AGT GGC TGA GCT TGG C }\end{array}$ & 50.0 & 115 & - & AY571877 \\
\hline $\mathrm{Nv}-22$ & MS & $\begin{array}{l}\text { ATT TCA CCG CGC TAT AAC } \\
\text { AGC TAG GGA AGA GGA TAC C }\end{array}$ & 54.2 & 202 & 220 & AY262041 \\
\hline $\mathrm{NvC1}-20$ & STS & $\begin{array}{l}\text { TGT AAA AGT AGT CCG CTT CG } \\
\text { TAT TTA TAT ATG GAA AAA GAG G }\end{array}$ & 50.0 & 125 & 142 & AY571878 \\
\hline $\mathrm{NvC1}-21$ & STS & $\begin{array}{l}\text { GTA ACA GTG AGA TAA ATG TG } \\
\text { TAG CAA CGA TAG TCC ACG }\end{array}$ & 50.0 & 148 & - & AY571880 \\
\hline $\mathrm{NvC1}-22$ & STS & $\begin{array}{l}\text { GCA GAG TCG AGG CAA G } \\
\text { TTA CCG GAG TTC GTT AAC }\end{array}$ & 50.0 & 206 & 217 & AY571881 \\
\hline $\mathrm{NvC1}-23$ & STS & $\begin{array}{l}\text { GAC TGA ATC TGG TGA TTT C } \\
\text { GGT CCT TAC ATT TCG GAC }\end{array}$ & 50.0 & 104 & - & AY571879 \\
\hline $\mathrm{NvC1-24}$ & STS & $\begin{array}{l}\text { TAC ATT GGT ATT GCT ATT GC } \\
\text { TAC AAT AGT CTT TGG ACA AC }\end{array}$ & 50.0 & 151 & - & AY571882 \\
\hline \multicolumn{7}{|c|}{ Chromosome 2} \\
\hline $\mathrm{Nv}-20$ & MS & $\begin{array}{l}\text { TGA CGA AGT ATC CGA GAA G } \\
\text { TCG AAA AAC GAT ATT GCT CG }\end{array}$ & 56.0 & 105 & 89 & AY262039 \\
\hline $\mathrm{Nv}-23$ & MS & $\begin{array}{l}\text { CAG CAT ACT CAA GCA AGC } \\
\text { GAT ACC TGA AGT TTG ATG C }\end{array}$ & 50.0 & 217 & - & AY262044 \\
\hline Nv-26 & MS & $\begin{array}{l}\text { TTC GCA GCT TTC CTT TGC } \\
\text { AGC AGC TAG TAT GAA CCG }\end{array}$ & 50.0 & 142 & 120 & AY262047 \\
\hline $\mathrm{NvC2}-14$ & STS & $\begin{array}{l}\text { CCC TTT CTC GTT TTC TGC } \\
\text { TAA TGA ATT CAA CTG TTA CTG }\end{array}$ & 50.0 & 120 & 122 & AY571883 \\
\hline \multicolumn{7}{|c|}{ Chromosome 3} \\
\hline $\mathrm{NvC3}-17$ & STS & $\begin{array}{l}\text { GCC AAG AAT CAA AGT AAT GG } \\
\text { TAT GGG TCT GCC TCT GG }\end{array}$ & 50.0 & 143 & 148 & AY571884 \\
\hline NvC3-18 & STS & $\begin{array}{l}\text { GCC CAA ATC ATG CTT TCG } \\
\text { GTT GTT CTT AAA TGT GTA TTC C }\end{array}$ & 50.0 & 104 & - & AY571885 \\
\hline \multicolumn{7}{|c|}{ Chromosome 4} \\
\hline $\mathrm{NvC4}-15$ & STS & $\begin{array}{l}\text { GCA GGG CTT TGT TAT AGC } \\
\text { CGA CGA AAC CGA AGT GG }\end{array}$ & 50.0 & 111 & - & AY571886 \\
\hline NvC4-16 & STS & $\begin{array}{l}\text { GAT AAA GCC GCC CGT TG } \\
\text { AAT TAG GTG ATT GAC TGA G }\end{array}$ & 50.0 & 90 & - & AY571887 \\
\hline $\mathrm{Nv}-21$ & MS & $\begin{array}{l}\text { TTG ATA TTG ATC GAG TAG TTC C } \\
\text { CTC CTA GAG GAA GCT TTG C }\end{array}$ & 46.8 & 177 & 165 & AY262040 \\
\hline $\mathrm{Nv}-24$ & MS & $\begin{array}{l}\text { CCG AAA TCC ACA TAG ACC } \\
\text { AGG AAC TCA TCA AGA CGG }\end{array}$ & 50.0 & 116 & 100 & AY262045 \\
\hline Nv-37 & MS & $\begin{array}{l}\text { ATA TTG CTT TTC CAG ACA CC } \\
\text { GCT ATT GTT ACT GCT CTG G }\end{array}$ & 46.0 & 191 & - & AY572846 \\
\hline Chromoso & & & & & & \\
\hline NvC5-19 & STS & $\begin{array}{l}\text { TGA TCT TGG AGA AGC TGG } \\
\text { CCC TGC TTA CAT TCT TCC }\end{array}$ & 50.0 & 128 & 129 & AY571888 \\
\hline $\mathrm{Nv}-25$ & MS & $\begin{array}{l}\text { TTG ACG GAG TAG TTC CAG } \\
\text { GTA AGT CTG CGG TAG CTG }\end{array}$ & 52.0 & 268 & 296 & AY262046 \\
\hline $\mathrm{Nv}-27$ & MS & $\begin{array}{l}\text { AAT ACT CGC TGT TCA ATC G } \\
\text { CGC TAG ATC GGA TTT CCG }\end{array}$ & 52.0 & 193 & 169 & AY262048 \\
\hline $\begin{array}{ll}\text { a } & \text { STS: } \\
\text { b } & \text { Ta: a }\end{array}$ & gged s & MS: microsatellite. & & & & \\
\hline
\end{tabular}


Fig. 3. Frequency distribution of the recovery rate of all mapped markers. Both marker populations (filled bars = LV-RAPD; empty bars = LV$\mathrm{ms})$ are not significantly different from each other and a normal distribution, respectively.

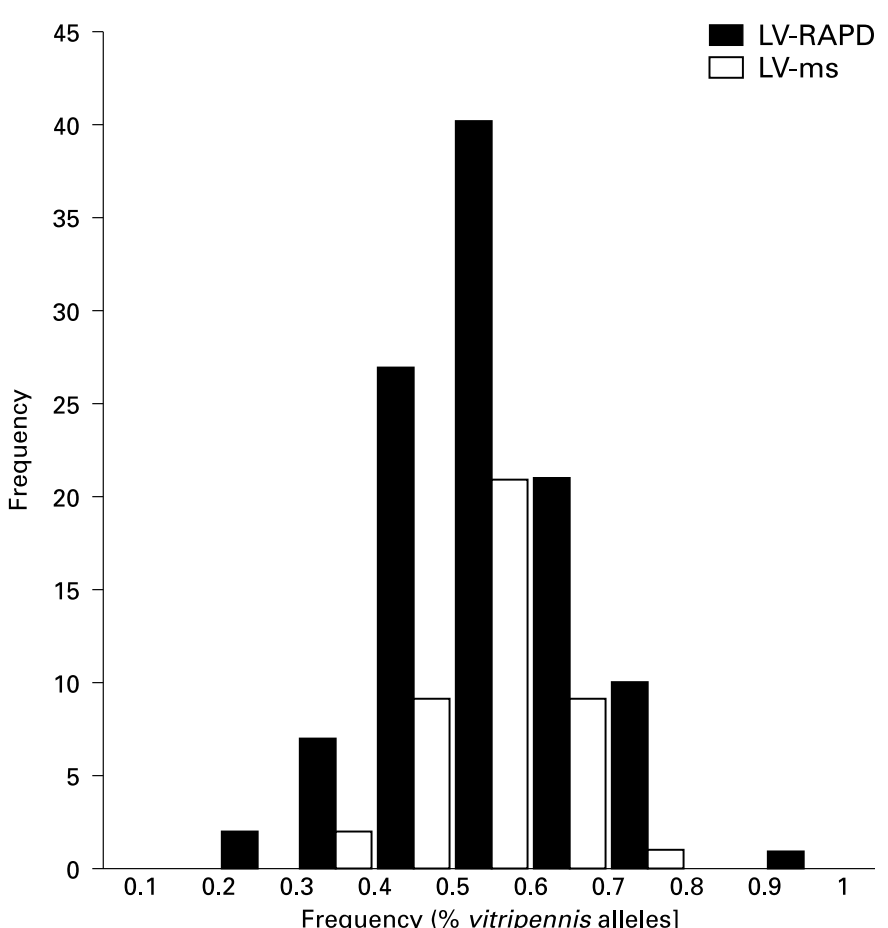

Table 2. Location and effect of significant QTL for wing size of an interspecific cross $(N$. longicornis $\times N$. vitripennis)

\begin{tabular}{|c|c|c|c|c|c|c|c|c|}
\hline Trait & $\begin{array}{l}\text { Associated marker } \\
\text { (chromosome) }\end{array}$ & Mean vit. & Mean lon. & $\begin{array}{l}\text { LOD } \\
\text { interval } \\
\text { mapping }\end{array}$ & $\begin{array}{l}\text { Genome wide } \\
\text { threshold } \\
0.05 / 0.01^{\mathrm{a}}\end{array}$ & $\begin{array}{l}\text { Explained additive } \\
\text { variation \% }\end{array}$ & $\begin{array}{l}\text { Recovery in \% } \\
\text { vitripennis }\end{array}$ & $\begin{array}{l}\text { Chi-square on } \\
\text { total numbers }\end{array}$ \\
\hline wile & Z20/410 (chr. 1) & 808.5 & 698.4 & 2.9 & $2.1 / 2.5$ & 19.9 & 43.2 & n.s. \\
\hline wile/ head & 1DF3 (chr. 1) & 20.0 & 18.1 & 2.3 & $2.3 / 3.2$ & 18.0 & 55.4 & n.s. \\
\hline wiwi/ head & $3 / 10$ (chr. 4) & 5.53 & 6.58 & 3.51 & $2.1 / 2.8$ & 22.9 & 50.8 & n.s. \\
\hline
\end{tabular}

Determined by a standard permutation test for each trait separately (Churchill and Doerge, 1994).

markers by linkage. This possibility turns the microdissection technique into a routinely usable method. Together with the currently developed BAC library for Nasonia at the CUGI (Clemson University Genomics Institute) this technique will in the future permit us to go in Nasonia more rapidly from observable behavioral polymorphisms, to QTL and finally the underlying gene/s (see also below for a possible application). These developments will make Nasonia a real model system for hymenopteran genetics and the study of the pre- and postzygotic hybridization barriers (Page et al., 2002).

The chromosomal anchored microsatellites will also serve as simple tools to accumulate markers for chromosomes in the Nasonia community because now markers developed in other laboratories can reliably be mapped to specific chromosomes.

For some of the tested wing size traits, significant QTL at the genome wide statistical threshold of 0.05 could be detected (Table 1) even with a limited number of markers (48 for wing size) and individuals tested (96 for wing size). The QTL for wing width on chromosome 4 mapped to the same position as a major QTL for wing width in another hybrid cross (Gadau et al., 2002). This might indicate that the same locus is responsible for the decrease in male wing size in $N$. vitripennis and $N$. longicornis. However, both species probably diverged from each other before the reduction in wing size started because $N$. longicornis is the sister taxon of $N$. giraulti where males have normal sized wings. Therefore, we might have an interesting case where similar selection pressures have led to changes in the same gene. However, we need to have a more fine grained analysis (getting the gene) to make a clear statement whether the homologous or a closely linked gene is responsible for the observed phenotypic change in wing size in $N$. longicornis and $N$. vitripennis. Once we have the gene we can also test whether the same nucleotide positions have been changed to produce a similar phenotype, i.e. smaller wings.

\section{Acknowledgement}

We thank Magdalene Westendorff for her help with the karyotyping. 


\section{References}

Beukeboom LW, Assem van den J: Courtship behaviour of interspecific Nasonia hybrids (Hymenoptera, Pteromalidae): a grandfather effect. Behav Genet 31:167-177 (2001)

Bordenstein SR, O‘Hara FP, Werren JH: Wolbachia induced bidirectional incompatibility precedes other hybrid incompatibilities in Nasonia. Nature 409:707-710 (2001).

Churchill GA, Doerge RW: Empirical threshold values for quantitative trait mapping. Genetics 138:963971 (1994).

Gadau J, Page JR Jr, Werren JH: Mapping of hybrid incompatibility loci in Nasonia. Genetics 153 : 1731-1741 (1999).

Gadau J, Page JR Jr, Werren JH: The genetic basis of interspecific differences in wing size in Nasonia (Hymenoptera; Pteromalidae): Major Quantitative Trait Loci and epistasis. Genetics 161:673-684 (2002).

Gershenzon SM: The genetic structure of the natural populations of Mormoniella vitripennis Wlk. (Chalcididae: Hymenoptera) [in Russian]. Zh Obshchei Biol 7:165-173 (1946).

Gokhman VE, Westendorff M: The chromosomes of three species of the Nasonia complex (Hymenoptera, Pteromalidae). Beitr Ent 50:193-198 (2000).

Imai HT, Taylor RW, Crosland MWJ, Crozier RH: Modes of spontaneous chromosomal mutation and karyotype evolution in ants with reference to the minimum interaction hypothesis. Jpn J Genet 63:159-185 (1988)
Jansen RC: Interval mapping of multiple quantitative trait loci. Genetics 135:205-211 (1993).

Jansen RC: Controlling the type I and type II errors in mapping quantitative trait loci. Genetics 136:871881 (1994).

Jansen RC, Stam P: High resolution of quantitative traits into multiple loci via interval mapping. Genetics 136:1447-1455 (1994).

Kosambi DD: The estimation of map distances from recombination values. Ann Eugen 12:172-175 (1944).

Lander ES, Green P, Abrahamson J, Barlow A, Daly MJ, Lincoln SE, Newburg L: MAPMAKER: An interactive computer package for constructing primary genetic linkage maps of experimental and natural populations. Genomics 1:174-181 (1987).

Müller S, Nuesser M, Wienberg J: Towards unlimited colors for fluorescence in situ hybridization (FISH). Chrom Res 10:223-232 (2002).

Nur U, Werren JH, Eickbush DG, Burke WD, Eickbush TH: A "selfish" B chromosome that enhances its transmission by eliminating the paternal genome. Science 240:512-514 (1988).

van Ooijen J, Boer MP, Jansen RC, Maliepaard C: MapQTL (tm) version 4.0: Software for the calculation of QTL positions on genetic maps. CPRODLO, Wageningen (1999).
Page RE Jr, Gadau J, Beye M: The emergence of Hymenopteran genetics. Genetics 160:375-379 (2002).

Rütten KB, Schulz I, Olek K, Uhl G: Polymorphic microsatellite markers in the spider Pholcus phalangioides isolated from a library enriched for $\mathrm{CA}$ repeats. Mol Ecol Notes 1:255-257 (2001).

Saul GB: Gene map of the parasitic wasp Nasonia vitri pennis ( = Mormoniella vitripennis) $2 \mathrm{n}=10$, in O’Brien GEJ (ed): Genetic Maps, pp 3.227-3.280 (Cold Spring Harbor Laboratory Press, Cold Spring Harbor 1993)

Shuker D, Lynch J, Peire Morais A: Moving from model to non-model organisms? Lessons from Nasonia wasps. BioEssays (in press).

Telenius H, Carter NP, Bebb CE, Nordenskjold M, Ponder BA, Tunnacliffe A: Degenerate oligonucleotid-primed PCR: General amplification of target DNA by a single degenerate primer. Genomics 13:718-725 (1992).

Weston RF, Qureshi I, Werren JH: Genetics of wing size difference between two Nasonia species. J Evol Biol 12:586-595 (1999)

Zeng Z: Theoretical basis for separation of multiple linked gene effects in mapping quantitative trait loci. Proc Natl Acad Sci, USA 90:10972-10976 (1993).

Zeng Z: Precision mapping of quantitative trait loci. Genetics 136:1457-1468 (1994). 